\title{
Dietmar W. Winkler, Li Tang. Hidden Treasures and Intercultural Encounters. Studies on East Syriac Christianity in China and Central Asia
}

\section{Christelle Jullien}

\author{
(2) OpenEdition \\ Journals \\ Édition électronique \\ URL : http://journals.openedition.org/abstractairanica/40902 \\ DOI : 10.4000/abstractairanica.40902 \\ ISSN : 1961-960X \\ Éditeur : \\ CNRS (UMR 7528 Mondes iraniens et indiens), Éditions de l'IFRI

\section{Édition imprimée} \\ Date de publication : 1 décembre 2013 \\ ISSN : 0240-8910 \\ Référence électronique \\ Christelle Jullien, « Dietmar W. Winkler, Li Tang. Hidden Treasures and Intercultural Encounters. \\ Studies on East Syriac Christianity in China and Central Asia », Abstracta Iranica [En ligne], Volume \\ 32-33 | 2013, document 353, mis en ligne le 01 juillet 2016, consulté le 05 octobre 2020. URL : http:// \\ journals.openedition.org/abstractairanica/40902; DOI : https://doi.org/10.4000/abstractairanica. \\ 40902
}

Ce document a été généré automatiquement le 5 octobre 2020.

Tous droits réservés 


\section{Dietmar W. Winkler, Li Tang.} Hidden Treasures and Intercultural Encounters. Studies on East Syriac Christianity in China and Central

\section{Asia}

Christelle Jullien

\section{RÉFÉRENCE}

Dietmar W. Winkler, Li Tang. Hidden Treasures and Intercultural Encounters. Studies on East Syriac Christianity in China and Central Asia. Wien - Berlin, LIT, 2009, 400 p.

(Orientalia-Patristica-Oecumenica, 1)

1 Dans cet ouvrage, les AA. ont cherché à réunir la documentation récente sur les communautés chrétiennes syro-orientales établies en Chine et en Asie Centrale. Il s'agit d'un volume collectif interdisciplinaire donnant des aperçus aussi bien archéologiques, théologiques, philologiques ou d'histoire religieuse. 


\section{AUTEURS}

\section{CHRISTELLE JULLIEN}

CNRS, Mondes iranien et indien, Paris 